\title{
EFFECTS OF SOME NARCOTIC ANALGESICS AND RELATED COMPOUNDS UPON THE EXTENSOR MONOSYNAPTIC REFLEX INHIBITION FROM CUTANEOUS NERVE AND HIGH THRESHOLD MUSCLE AFFERENTS
}

\author{
Nobuyoshi IWATA and Yutaka SAKAI \\ Medical Laboratory for Pharmacology, Central Research Laboratories. \\ Sankyo Co., Ltd., Sinagawa-ku, Tokyo \\ Reccived for publication January 29, 1971
}

In a preceding paper we described that small doses of fentanyl and morphine depressed the late phase of the inhibition of extensor spinal monosynaptic reflex (MSR) induced by the stimulation of either Aio fibers of the cutancous nerve or high threshold muscle afferents (1).

Since it has already been reported that pain impulses may be transmitted through Group III muscle and cutaneous Ao and $C$ afferent fibers (2), it was considered that this depressive action of morphine and fentanyl might be related to their analgesic action. In order to test this possibility, an attempt was made to study and compare, as the first step, effects on this neuronal system of some other narcotic analgesies and those of non-nareotic analgesics, narcotic antagonists and some compounds with similar chemical structures to morphine but without analgesic activity. The following drugs were tested on this inhibitory transmission from flexor reflex afferents. Group 1, narcolic analgesics; oxymorphone, dimethylthiambutene and azabicyclane, group 2, non-narcotic analgesics; pentazocine and Aspirin, group 3, narcotic antagonists; nalorphine and levallorphan, and group 4, compounds with similar chemical structures to morphine but without analgesic activity; 14-hydroxy-dihydro-6 $\alpha$-thebainol (3) and its $6 \beta$ isomer (3).

It was previously reported (7) that the analgesic potency of azabicyclane, a newly synthetized compound, was about 3-6 times greater than that of meperidine, and in spite that this drug induced no significant loss of body weight in rats during the withdrawal periods after 4 weeks, azabicyclane had some narcotic properlies such as follows; $l$ ) the antagonism to the analgesic effect by nalorphine, 2) rapid development of torelance to analgesic effect, 3) Straub tail reaction in mice, etc. Therefore, in this paper azabicyclane was included in narcotic analgesic group.

The results will clearly show that the depressant action on this inhibitory system in the spinal cord is inherent among narcotic analgesics (including azabicyclane), but is not shared by drugs of the other categories.

\section{METHODS}

Eleven adult cats were used. Experimental procedures were similar to those described in the previous paper (1). Collar-type clectrodes were attached on the quadriceps 
and medial gastrocnemius-soleus ( $\mathrm{mG}-\mathrm{S}$ ) nerves for stimulation and two of these were implanted to the saphenous nerve, one for stimulation at proximal and the other for recording at distal part of the nerve. The monosynaptic reflex evoked by the stimulation of the MG-S nerve was recorded from $L_{\tau}$ ventral root.

The time course of the drug effects were tested against the inhibition obtained at a fixed interval (about $20 \mathrm{msec}$ ) between conditioning and testing stimulation. The amount of inhibition was measured as the difference in MSR amplitude before and about $20 \mathrm{msec}$ after conditioning shock to the afferent nerve. Drug effects on this inhibition was expressed as the amount of inhibition after drug injection relative to that obtained before drug injection.

Drugs tested are as follows and their chemical structures are shown in Fig. 1; azabicyclane (Sankyo), oxymorphone (Sankyo), morphine (Sankyo), dimethylthiambutene

\section{Morphine}

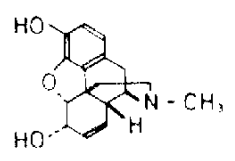

\section{Fentanyl}

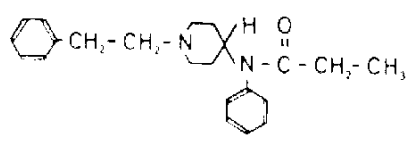

Dimethylthiambutene<smiles>CC(C=C1C2CCC12)N(C)C</smiles>

Nalorphine

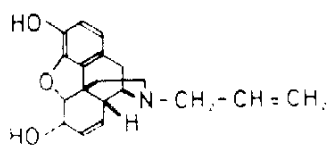

14-Hydroxy-dihydro$6 \alpha$-thebainol

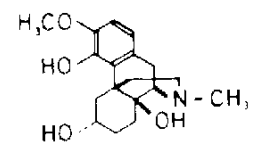

\section{Oxymorphone}

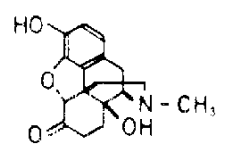

Azabicyclane<smiles>COC1(C)CC2CC(CCN2C)C12CCCC2</smiles>

Pentazocine

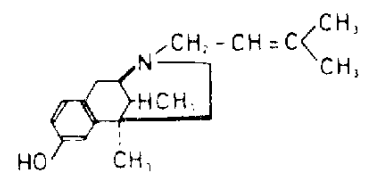

Levallorphan<smiles>C=CCN=C1CCCC1C1CCCC1</smiles>

14-Hydroxy-dihydro$6 ß$-thebainol

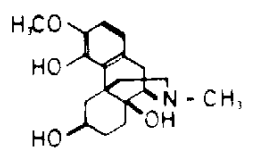

FiG. 1. Chemical structures of compounds tested. 
(Ono Pharmaceutical Co.), pentazocine (Sankyo), nalorphine (Sankyo), levallorphan (Takeda Chemical Industries), 14-hydrooxy-dihydro- $6 \alpha$-thebainol and its $6 \beta$ isomer (synthetized in our Research Laboratories) and Aspirin (Nihon Kayaku). These drugs except nalorphine, levallorphan, pentazocine and Aspirin were dissolved in physiological saline and diluted to $0.1 \%$ (oxymorphone) or $1 \%$ (azabicyclane, dimethylthiambutene, 14-hydroxydihydro- $6 \alpha$-thebainol and its $6 \beta$ isomer). Pentizocine, nalorphine and levallorphan were administered without dilution of injection solution. Aspirin was dissolved in $1 \mathrm{~N} \mathrm{NaOH}$ solution $(10 \%$ solution) and was diluted to $1 \%$ solution with physiological saline. All drugs were administered intravenously through a catheter inserted to the femoral vein contralateral to the experimental side.

\section{RESULTS}

Effects of some narcotic analgesics upon the MSR inhibition from cutancons nerve and high threshold muscle afferents

I) Azabicyclane: As described in the previous paper (1), the cutaneous inhibition was seen from about 5 to $30-35$ msec after the conditioning stimulation of the saphenous nerve at supramaximal intensity for A fibers, whereas at a low intensity stimulation which nearly maximal nerve action potential of $\Lambda \propto$ fibers but no Aó potential was obtained, the cutaneous inhibition was observed from about 5 to $20 \mathrm{msec}$.

As is illustrated in Fig. 2, the late phase of the cutaneous inhibition produced by a
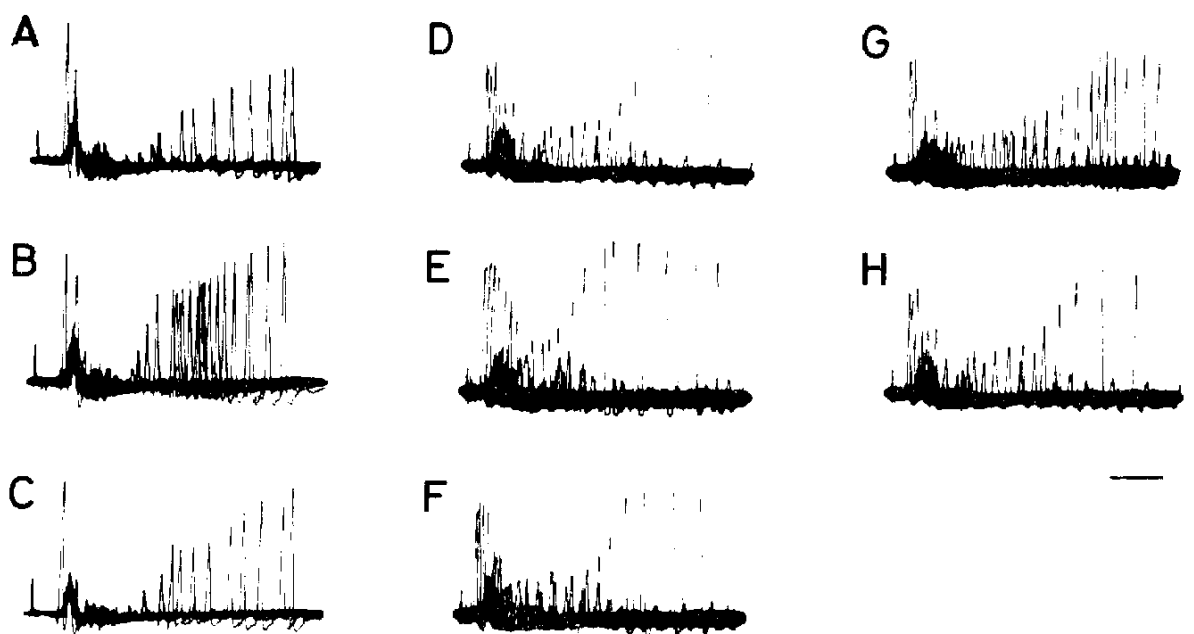

FiG. 2. Effects of azabicyclane, dimethylthiambutene and 14-hydroxy-dihydro-6r-thebainol upon the cutaneous inhibition.

$A$ to $C, D$ to $F$ and $G$ to $H$ illustrate effects of azabicyclane, dimethylthiambutene and 14-hydroxy-dihydro-6o-thebainol, respectively. A,D and G; before, B ; 5 minutes and $C ; 90$ minutes after the administration of azabicyclane $(5 \mathrm{mg} / \mathrm{kg})$, $\mathrm{E} ; 7$ minutes and $\mathrm{F} ; 90$ minutes after administration of dimethylthiambutcne (5 $\mathrm{mg} / \mathrm{kg}) \mathrm{H} ; 10$ minutes after 14-hydroxy-dihydro-6 $\alpha$-thebainol injection $(10 \mathrm{mg} / \mathrm{kg})$. Note that the late phase of the cutaneous inhibition was depressed (B) or blocked completely (E) by narcotic analgesics but little, depressed by non-narcotic compound (H). Time, $10 \mathrm{msec}$. 
shock supramaximal for Ao fibers was depressed after administration of azabicyclane $(5 \mathrm{mg} / \mathrm{kg})(\mathrm{B})$ and the duration of the cutancous inhibition was shortened from about 35 msec to $15 \mathrm{msec}$, as was seen with fentanyl and morphine (1).

The time courses of this effect at 3 different doses $(0.5,1$ and $5 \mathrm{mg} / \mathrm{kg})$ in 3 cats were illustrated in Fig. 3. The cutaneous inhibition was almost uninfluenced at doses less than $0.5 \mathrm{mg} / \mathrm{kg}$ (crosses) and it was slightly depressed (about $25 \%$ ) at a dose of $1 \mathrm{mg} / \mathrm{kg}$ (filled circles). With these doses, the MSR was neither depressed nor enhanced. When $5 \mathrm{mg} /$ $\mathrm{kg}$ was administered, the cutaneous inhibition was depressed by about $60 \%$ (open circles). This effect started to manifest as soon as the completion of the drug administration, attaining maximum in 5-10 minutes and thereafter gradually declined. About 90 minutes was necessary for almost complete recovery (Fig. 2C and Fig. 3). The amplitude of the MSR was slightly depressed (about 10\%) at this dose. This effect was confirmed in 19 trials in 8 cats $(6$ trials with $5 \mathrm{mg} / \mathrm{kg}, 3$ trials with $3 \mathrm{mg} / \mathrm{kg}, 6$ trials with $1 \mathrm{mg} / \mathrm{kg}, 2$ trials with $0.5 \mathrm{mg} / \mathrm{kg}$ and 2 trials with $0.1 \mathrm{mg} / \mathrm{kg}$.

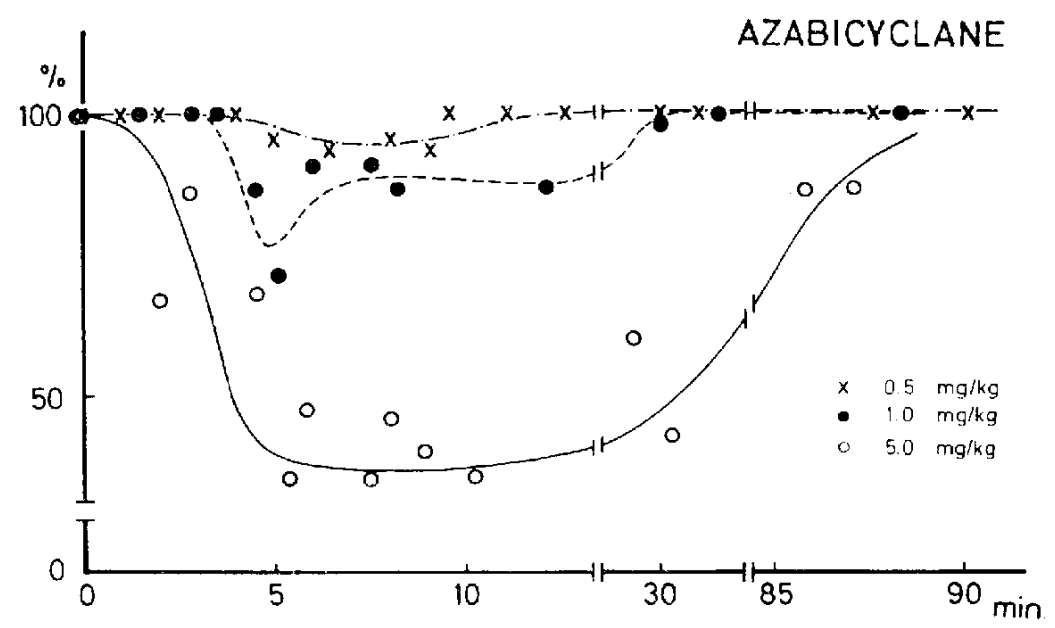

Fic. 3. Time courses of azabicyclane effect at 3 different doses.

Open circles, crosses and filled circles demonstrate as indicated in the graph. The ordinate shows the relative amount of MSR inhibition as measured about $20 \mathrm{msec}$ after conditioning shock to the afferent nerve at various time after the drug administration to that obtained before drug application.

2) Oxymorphone: The late phase of the cutaneous inhibition was also depressed and/or blocked by oxymorphone. The time cousses of oxymorphone effect at 3 different doses $(0.05,0.1$ and $0.25 \mathrm{mg} / \mathrm{kg})$ were studied in the same manner as that for azabicyclane. The cutaneous inhibition was slightly depressed at a dose of $0.05 \mathrm{mg} / \mathrm{kg}$ (Fig. 4, open circles), but at a dose of $0.1 \mathrm{mg} / \mathrm{kg}$, it was supressed by more than $50 \%$ about 510 minutes after administration and this effect declined with time but lasted for about 1 hour (crosses). At a higher dose $(0.25 \mathrm{mg} / \mathrm{kg})$, the late phase of the cutaneous inhibition was almost completely blocked about 5 to 10 minutes after administration and this effect gradually declined with time and eventually disappeared in about 90 minutes. This was confirmed in 7 trials in 3 cats (2 trials at $0.25 \mathrm{mg} / \mathrm{kg}, 3$ trials at $0.1 \mathrm{mg} / \mathrm{kg}$ and 2 trials at $0.05 \mathrm{mg} / \mathrm{kg}$ ). 


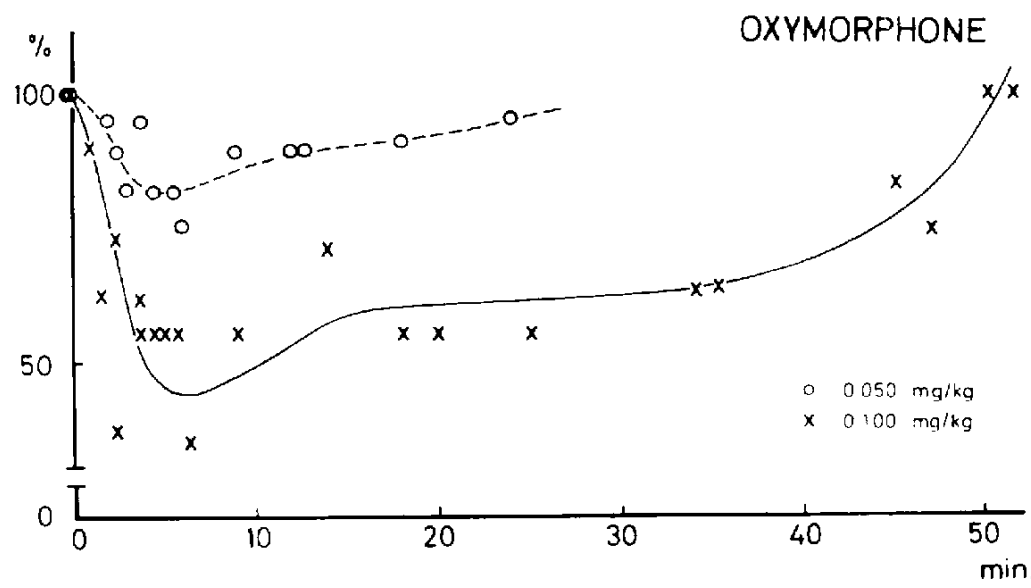

Fic. 4. Time courses of oxymorphone effect at 2 different doses. Ordinate and abscissa are the same as Fig. 3.

3) Morphine: As described in our previous paper (1), morphine (more than $1 \mathrm{mg}$ / $\mathrm{kg}$ ) blocked the late phase of the cutaneous inhibition. The dose effect relation was examined at smaller doses of morphine at fixed interval between conditioning and testing stimuli of about $20 \mathrm{msec}$. Results demonstrated that it had little effect on it at $0.1 \mathrm{mg}$ / $\mathrm{kg}$. slightly depressed it (about $25 \%$ ) at $0.3 \mathrm{mg} / \mathrm{kg}$ and inhibited it to a half of control level at a dose of $0.5 \mathrm{mg} / \mathrm{kg}$. These effects continued over the observation period of about 1 hour.

4) Dimethylthiambutene: As seen in Fig, 2, dimethylthiambutene also produced a similar effect at a dose of $5 \mathrm{mg} / \mathrm{kg}$ (E) and the similar time course of action was obtained to that of azabicyclanc. This effect almost completely disappcared about 90 minutes after administration (F).

The MSR inhibition caused by the stimulation of high threshold muscle afferents of quadriceps nerve was decreased in its late phase after administration of azabicyclane (5 $\mathrm{mg} / \mathrm{kg}$ ), oxymorphone $(0.1$ and $0.25 \mathrm{mg} / \mathrm{kg}$ ) and dimethylthiambutene $(5 \mathrm{mg} / \mathrm{kg}$ ) without any effect upon the early one as was the case in fentanyl and morphine (1).

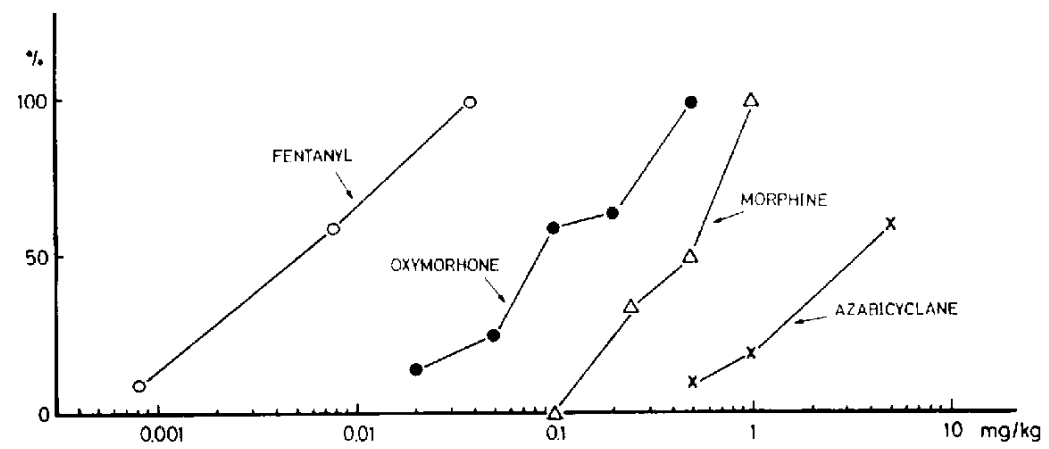

Frg. 5. Dose-response relationship of some narcotic analgesics upon the cutaneous inhibition. Ordinate; maximal effect of blocking action of the late phase of the cutancous inhibition. Abscissa ; dose of drugs. 
In all of these narcotic analgesics, the amplitude of the MSR and the early phase of the cutaneous inhibition evoked from $A \alpha$ afferent fibers were almost uninfluenced within the range of the doses tested.

As described above and in the previous paper (1), all narcotic analgesics tested (morphine, fentanyl, azabicyclane, oxymorphone and dimethylthiambutene) commonly depressed the late phase of the MSR inhibition evoked by the stimulation of cutaneous nerve and high threshold muscle afferents at their relatively small doses for each drug.

The peak effect of fentanyl (calculated from data in the preceding paper obtained at fixed conditioning-test intervals of about $15 \mathrm{msec}$ ), morphine, oxymorphone and azabicyclane upon the late phasc of the cutaneous inhibition was plotted against their doses in Fig. 5.

Effects of other compounds upon the MSR inhibition from cutaneous and high threshold muscle afferents

Pentazocinc, a known non-narcotic analgesic (4), had little effect upon either the

TABle 1. Depressive action of the late phase of the Cutaneous inhibition and analgesic activity.

\begin{tabular}{|c|c|c|c|c|c|}
\hline \multirow{2}{*}{ Compounds } & \multicolumn{2}{|c|}{$\begin{array}{l}\text { Release from } A \hat{o} \\
\text { inhibition }\end{array}$} & \multicolumn{3}{|r|}{ Analgesic action } \\
\hline & Dose & Results & Dose & Results & Methods (References) \\
\hline \multirow[t]{3}{*}{ Fentanyl } & $8 \quad / \mathrm{g} / \mathrm{kg}$ & t & $16 \quad \mu \mathrm{g} / \mathrm{kg}$ & - & Rabbits toothpulp stimulation (i.v.) (11) \\
\hline & 40 & + & 47 & - & \\
\hline & 80 & + & & & \\
\hline \multirow[t]{4}{*}{ Morphine } & $0.5 \mathrm{mg} / \mathrm{kg}$ & + & & & \\
\hline & 1 & & $1 \mathrm{mg} / \mathrm{kg}$ & - & Rabbit toothpulp stimulation (i.v.) (11) \\
\hline & 3 & + & 3 & $\therefore$ & \\
\hline & 10 & + & 10 & $\therefore-$ & \\
\hline \multirow[t]{3}{*}{ Azabicyclane } & 0.5 & ... & & & \\
\hline & 1 & -- & 2.5 & - & Mice Haffner $\mathrm{ED}_{\mathrm{s} \text { ( }}$ (s.c.) (7) \\
\hline & 5 & + & & & \\
\hline \multirow[t]{3}{*}{ Oxymorphone } & 0.05 & - & & & \\
\hline & 0.1 & + & 0.16 & + & Mice Haffner $\mathrm{ED}_{j 0}$ (s.c.) (3) \\
\hline & 0.25 & + & & & \\
\hline Dimethylthiambutene & 5 & + & $5-10$ & t & Dogs $(8)$ \\
\hline \multirow[t]{2}{*}{ Pentazocinc } & 3 & $\cdots$ & & & \\
\hline & 10 & - & 8 & 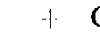 & Cats toothpulp stimulation (s.c.) (6) \\
\hline \multirow[t]{2}{*}{ Aspirin } & 10 & - & 3.8 & + & Dog bradykinin-evoked pain (i.a.) (5) \\
\hline & 30 & - & & & \\
\hline \multirow[t]{2}{*}{ Nalorphine } & 0.5 & - & & & \\
\hline & 1 & - & 16 & - & Cats toothpulp stimulation (s.c.) (6) \\
\hline Levallorphan & 1 & - & $0.016 \mathrm{~mm} / \mathrm{kg}$ & + & Rabbits toothpulp stimulation (i.v.)(9) \\
\hline \multirow{2}{*}{$\begin{array}{l}\text { 14-Hydroxy-dihydro- } \\
\text { 6x-thebainol }\end{array}$} & 5 & - & & & \\
\hline & 10 & - & $100 \mathrm{mg} / \mathrm{kg}<$ & $<-$ & Mice Haffner $\mathrm{ED}_{50}$ (s.c.) (3) \\
\hline \multirow{2}{*}{$\begin{array}{l}\text { 14-Hydroxy-dihydro- } \\
6 \alpha \text {-thebainol }\end{array}$} & 5 & -- & & & \\
\hline & 10 & - & $100 \mathrm{mg} / \mathrm{kg}<$ & $<-$ & Mice Haffner $\mathrm{ED}_{50}$ (s.c.) \\
\hline
\end{tabular}


amplitude of the MSR or MSR inhibition from cutaneous nerve and high threshold muscle afferents at a small dose ( $3 \mathrm{mg} / \mathrm{kg})$. However, at a higher dose (10 $\mathrm{mg} / \mathrm{kg})$ the blood pressure fell to about a half of control level and the MSR was remarkably depressed in amplitude. Even in this state, the cutaneous inhibition still remained unaffected.

Aspirin $(10,30 \mathrm{mg} / \mathrm{kg})$, nalorphine $(0.5,1 \mathrm{mg} \mathrm{kg})$, levaliorphan (1 mg/ $\mathrm{kg})$, 14-hydroxy-dihydro- $6 \alpha$-thebainol $(5,10 \mathrm{mg} / \mathrm{kg})$ and its $6 / 3$ isomer $(5,10 \mathrm{mg} / \mathrm{kg})$ did not cause any effects on either the MSR inhibition from small fibers described as above or the amplitude of the MSR. One example of $10 \mathrm{mg} / \mathrm{kg}$ of 14-hydroxy-dihydro- $6 \alpha$-thebainol is illustrated in Fig. 2 ( $G$ and $H$ ).

Table 1 summarizes the depressive action on the late phase of the cutancous inhibition of all the compounds tcsted together with the analgesic doses reported in the literatures. In this Table, the releases from cutaneous inhibition are expressed as "...." where the cutaneous inhibition was depressed more than $50 \%$ of control state after the drug administration at designated dose.

\section{DISCUSSION}

Present experiments clearly demonstrated that all narcotic analgesics tested have common characteristics of specifically blocking at small doses the late phase of the inhibition of extensor spinal monosynatic reflex evoked from cutaneous and high threshold muscle afferents. As shown in the previous paper (1), the phase of the inhibition depressed by these drugs is produced by the stimulation of the cutaneous Ao and high threshold muscle afferent fibers. This blockage of the inhibition is not a secondary one caused by either the change in respiration or blood pressure, because animals were maintained under artificial respiration and the blood pressure was kept roughly constant level. The fact that the late phase of the cutancous inhibition was still observable when the blood pressure fell considerably after the administration of pentazocine also supports this notion.

Although data on analgesic activities of the compounds as examined in behavioural studies in cats are not available, it is apparent that doses at which these narcotic-analgesics depressed the MSR inhibition from Ai cutancous afferent fibers are close to those for analgeise action of individual drugs reported in mice, rabbits, cats and dogs (Table 1).

In contrast to the uniform effectiveness in blocking the MSR inhibition of the narcotic analgesics which vary considerably in their chemical structures, compounds closely related chemically to morphine but devoid of analgesic activity or antagonistic to narcotics lack the blocking effect on this spinal mechanism. These observations clearly show that the blockage of the spinal inhibitory system is an essential feature of narcotic analgesics and is not separable from the analgesic action of these drugs. In view of these facts and the notion that pain impulses are presumably conveyed through Group III muscle and high threshold cutaneous afferents such as $\mathrm{A} i$ and $\mathrm{C}$ fibers, it is strongly suggested that narcotic analgesics have common site(s) of action in the spinal cord as regard to the blockage of the MSR inhibition from high threshold afferents and this site(s) is essentially the same or closely related 10 as of their analgesic action. It is clear, however, that the effect 
described can not be said in general to be related to analgesic activities per se, since nonnarcotic analgesics such as pentazocine and aspirin which are supposed to have different mechanisms of analgesic action from narcotic analgesics $(4,5,10)$ are devoid of this effect.

\section{SUMMARY}

In view of the selective blockage by small doses of morphine and fentanyl of the late phase of the MSR inhibition from cutancous $\mathrm{A} o$ and high threshold muscle afferents, an attempt was made to sec whether this effect is related to the analgesic action of these drugs. by comparing the effectiveness on this system of some narcotic analgesics, non-narcotic analgesics, narcotic antagonists, and compounds chemically related to morphine but devoid of analgesic action and corrclating this to analgesic activity of each drug.

It was clarified that all narcotic analgesics tested showed in common the same suppressive effect as of fentanyl and morphine on this inhibitory system. Doses necessary for this effect were close to those for analgesic action of each drug reported in literatures. Other drugs than narcotic analgesics were devoid of this blocking action on the MSR inhibition.

From these results it is considered that narcotic analgesics have common sites of action in spinal cord and this was discussed in relation with their analgesic action.

\section{REFERENCES}

1) Iwata, N. and Sakat, Y.: Jap. J. Pharmac. 21, 427 (1971)

2) BISHOP, G.H.: J. Nerve Ment. Dis. 128, 89 (1959)

3) Seki, I., Takagi, H. and Kobayashi, S.: Yakugaku Zasshi 84, 280 (1964)

4) Blumbrog, H., Wolf, P.F. And Daytox, H.B.: Proc. Soc. exp. Biol. Med. 118, 763 (1965)

5) Straw, R.N. and Mitchfl.t, C.L.: J. Pharmar. exp. Ther. 146, 7 (1964)

6) MitChelL, C.L.: Arch. int. Pharmacodyn. Therr. 164, 427 (1966)

7) Kobayashi, S., Hasfgawa, K., Oshima, T. axd Takagi, H.: Toxic, appl. Pharmac. 17, 344 (1970)

8) Adamson, D.W. and Gress, A.F.: Nature, Lond. 165, 122 (1950)

9) Yim, G.K.W., Krastivg, E.H., Gross, E.G. and Mitchell, C.W.: J. Pharmace exp. Ther. $115,96(1955)$

10) Lim, R.K.S., Krauthamer, G., Guzman, F. nnd Fulp, R.R.: Proc. natn. Acad. Sci. U.S.A. 63, $705(1969)$

11) Sakal, Y., Iwata, N., Mori, M. мND Nisinjma, Y.: Folia pharmac. jap. 67 (in press) (1971) 